Pak. j. sci. ind. res. Ser. B: biol. sci. 201255 (2) 82-92

\title{
Effects of Different Sources of Organic Waste Application on the Growth and Biomass Production of Kenaf (Hibiscus cannabinus L.)
}

\author{
Md. Shayeb Shahariar ${ }^{\mathrm{a} *}$, Shahrima Tahsin ${ }^{\mathrm{a}}$, Md. Nasimul Gani ${ }^{\mathrm{b}}$ and Shah Muhammad \\ Imamul Huq ${ }^{c}$ \\ ${ }^{a}$ Soil and Environment Section, Biological Research Division, Bangladesh Council of Scientific and Industrial \\ Research (BCSIR), Dr. Qudrat-I-Khuda Road, Dhanmondi, Dhaka-1205, Bangladesh \\ bSoil Science Division, Bangladesh Jute Research Institute (BJRI), Manik Mia Avenue, Sher-e-Bangla Nagar, \\ Dhaka-1207, Bangladesh \\ 'Department of Soil Water and Environment, University of Dhaka, Dhaka-1000, Bangladesh
}

(received October 6, 2011; revised April 27, 2012; accepted May 24, 2012)

\begin{abstract}
The growth and biomass productivity of kenaf (Hibiscus cannabinus L.) grown with different sources of organic waste viz. sewage sludge, poultry litter, cow dung and rice straw application were observed in a field experiment. Organic wastes were applied at the rate of $5 \mathrm{t} / \mathrm{ha}$ and were compared with recommended dose of fertilizers and control. The plants were harvested at 120 days after sowing (at the flowering stage). Different sources of organic wastes had a significant effect $(P<0.05)$ on the growth indices and biomass productivity of kenaf. Increased plant growth and biomass productivity were in the order of sewage sludge $>$ cow dung $>$ poultry litter $>$ rice straw treatments. Among the four sources of organic wastes, sewage sludge treated plot produced the highest mean biomass of $23.33 \mathrm{t} /$ ha (dry weight basis) which was $14.64 \%$ higher than the mean biomass production from control plot.
\end{abstract}

Keywords: biomass production, growth, kenaf, organic waste, poultry litter, sewage sludge

\section{Introduction}

Kenaf (Hibiscus cannabinus L.), a member of the Malvaceae family endemic to Africa (Bassam, 1998) is a warm-season, annual, herbaceous plant that produces high quality cellulose. Although tropical in origin, kenaf cultivars are well adapted to a wide geographical and climatic range (Meints and Smith, 2003). Kenaf is a high yielding plant achieved particular attention as an alternative crop for energy and paper pulp production. It is a good source of low cost natural fibre for a wide range of industrial products, examined for its possible uses in bio-energy sector (Alexopoulou et al., 2004) and has long been used to provide pulp for the paper industry (Taylor and Kugler, 1992). Kenaf has been reported to be 3-5 times more productive per unit area than pulpwood trees, producing pulp with quality equal or superior to that of many wood species (Francois et al., 1992). United States Department of Agriculture (USDA) determined that kenaf is an excellent cellulose fibre source for a wider range of paper products such as newsprint, bond paper, and corrugated liner board.

*Author for correspondence; E-mail: shayeb.shahariar@gmail. com
It is also determined that pulping kenaf required less energy and chemicals for processing as compared to standard wood sources (White et al., 1970; Wilson et al., 1965; Nelson et al., 1962; Nieschlag et al., 1960). Recent research and development efforts have further increased the diversity of uses of kenaf by demonstrating its suitability in building materials like particle boards of various densities, thicknesses, with fire and insect resistance, as a substrate mixture adsorbents, textiles, livestock feed and as fibres in new and recycled plastics (injected molded and extruded) (Nielsen, 2004; Webber and Bledsoe, 2002; McMillin et al., 1998; Webber, 1993a; Webber and Bledsoe, 1993). The prospects of kenaf becoming as an alternative crop to obtain large biomass amounts at low production cost (Quaranta et al., 2000). To achieve this, agronomic practices such as soil amendment may be able to improve its productivity, growth and biomass quality (Alexopoulou et al., 2007; Muir, 2002; 2001). Considerable information on kenaf agronomy and biomass productivity has been reported from Australia (Muchow and Carberry, 1993; Carberry et al., 1992; Carberry and Muchow, 1992; Muchow, 1992; Wood et al., 1983; Wood and Muchow, 
1980) and USA (Bhardwaj et al., 2005; Nielsen, 2004; Meints and Smith, 2003; Banuelos et al., 2002; Webber and Bledsoe, 2002; McMillin et al., 1998; Webber, 1996).

Management problems with sewage sludge and poultry litter waste have become so critical in recent years that many efforts are underway to solve the problem in a cost-effective manner. The accumulation of this type of organic waste poses a growing environmental problem and of its disposal. Just like other similar environmental issues, the pollution load of poultry waste in certain areas of concentrated farms has become so great that poultry farm owners are beginning to understand the problem (Waste Concern, 2005). Recycling of this waste as a fertilizer is an economically and environmentally attractive option. Determining the availability of nutrients in these wastes is important if such wastes are to provide sufficient nutrients to crops while causing minimal environmental damage (Andrés et al., 2010). The major sources of organic waste that can be used in agriculture are poultry litter and sewage sludge but other such as crop residues can also be applied to land (Westerman and Bicudo, 2005). The application of stabilized sewage sludge to the land has become an attractive option since it could reduce a potential source of pollution as well as the need for synthetic fertilizers (Cuevas et al., 2003). One of the main concerns associated with the land application of sludge is the availability and mobility of macronutrients and trace metals (McBride et al., 2004; Shober et al., 2003; Korboulewsky et al., 2002). Sewage sludge and poultry litter products are good sources of plant nutrients and they have large amounts of organic matter that can improve the physical and biological properties of soils; thus offer potential benefits in crop production.

Soil fertility is an important aspect for biomass production of kenaf (H. cannabinus L.). In research in Florida comparing differences in kenaf stalk production and fibre content between a highly organic Everglades peat soil and a low organic sandy soil, it was observed that with proper fertilization both crops grew to the same height and produced the same fibre yields, but the peat-grown kenaf produced 32\% greater green weight (Pate et al., 1954). In a soil fertility study in Oklahoma using five nitrogen application rates on a fine sandy loam soil, it was determined that stalk yield tended to increase as $\mathrm{N}$ application rates increased up to $168 \mathrm{~kg} \mathrm{~N} / \mathrm{ha}$ (Webber, 1996). Although temperature and moisture conditions for organic decomposition in the field are often suboptimal, the results obtained in this study provide an indication of the amounts of $\mathrm{N}$, $\mathrm{P}$ and $\mathrm{K}$ that might be supplied by sewage sludge, poultry litter and cow dung at the rate applied. Nevertheless, long-term field studies are needed to obtain more accurate assessments of their fertilizing capacity and environmental impact, especially excessive accumulation of nutrients in the soil following repeated application.

One of the main concerns associated with the land application of sewage sludge and poultry litter is the availability and mobility of macronutrients and trace metals in soil. The method in which sludge is processed may significantly change its trace element concentration and the availability of its macro and/or micronutrients (Walter et al., 2006; Richards et al., 2000; Krogman et al., 1998; Wen et al., 1997; Misslebrook et al., 1996). An inadequate $\mathrm{N}$ supply by sewage sludge and poultry litter could reduce crop yields, while surplus $\mathrm{N}$ might reduce crop quality and lead to an accumulation of excess soil $\mathrm{NO}_{3}-\mathrm{N}$, which is subject to leaching (Cogger et al., 2004; Shober et al., 2003). Applications of sewage sludge and poultry litter based on crop $\mathrm{N}$ requirements can result in raised soil P levels (DeLaune et al., 2004; Sims and Pierzynski, 2000). Such increases may be associated with an increase in $\mathrm{P}$ in surface water runoff, which can contribute to the eutrophication of water bodies. Research is still needed to improve the understanding of the fate of mineralized $\mathrm{N}$ and $\mathrm{P}$ following the application of organic wastes. Further, care should be taken that the biosolids do not introduce an excess of heavy metals that become labile in the soil; these can have significant negative effects on groundwater, biological soil fertility and crop quality (McBride et al., 1999).

The present field experiment was conducted with an objective to apply organic wastes in agricultural fields as source of organic matter for higher biomass production as well as to establish an economically and environmentally attractive management option.

\section{Materials and Methods}

Experimental site. A field experiment was carried out to observe the biomass production of kenaf (Hibiscus cannabinus L.) due to amendment of soil with various sources of organic wastes. The experiment was carried out in the experimental field (Block-9) of Jute Agricultural Experimental Station (JAES), Bangladesh Jute Research Institute (BJRI), Manikganj, 


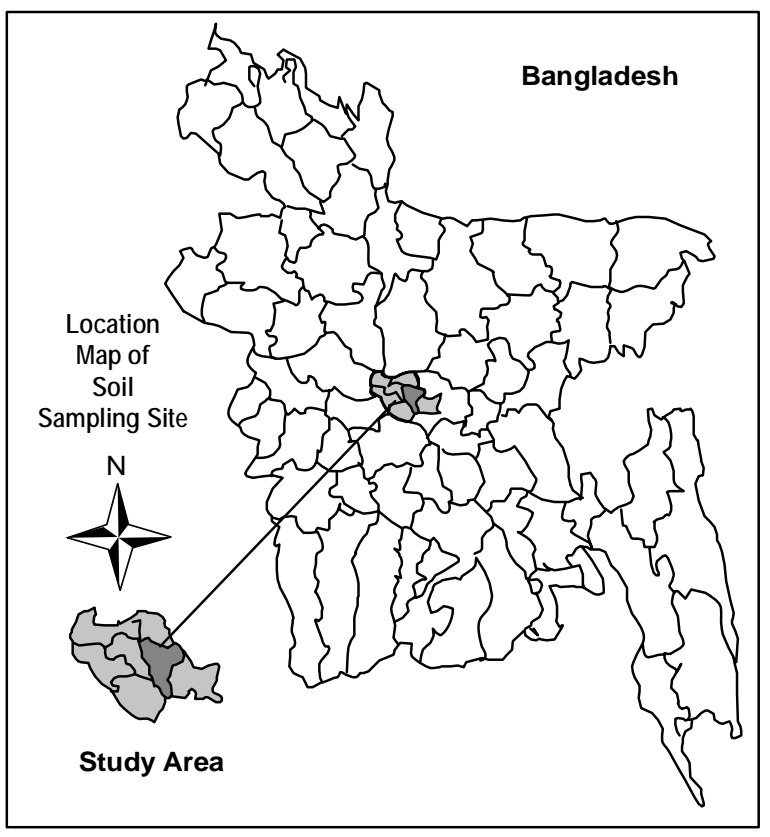

Bangladesh during March to July 2008. The research site is located at $23^{\circ} 53.034^{\prime} \mathrm{N}$ and $90^{\circ} 02.265^{\prime} \mathrm{E}$ (Fig. 1). The soil of the experimental area belongs to the Young Brahmaputra and Jamuna Floodplains under Agro Ecological Zone-8 (BARC, 2005). The land type of the selected plot is medium highland and the soil series is Sonatala. The experimental site is in the subtropical climatic zone characterized by heavy rainfall during the months from May to September. Warmest and coldest months were May (Average $32.3^{\circ} \mathrm{C}$ ) and January (Average $10.5{ }^{\circ} \mathrm{C}$ ), respectively during the experimental year. Total rainfall during the cropping period was $2606 \mathrm{~mm}$.

Field experiment and management. Experiment was carried out in a randomized complete block design (RCBD). A total of six (6) treatments along with a control (where no organic waste was applied) were distributed randomly in each plot at each replication.

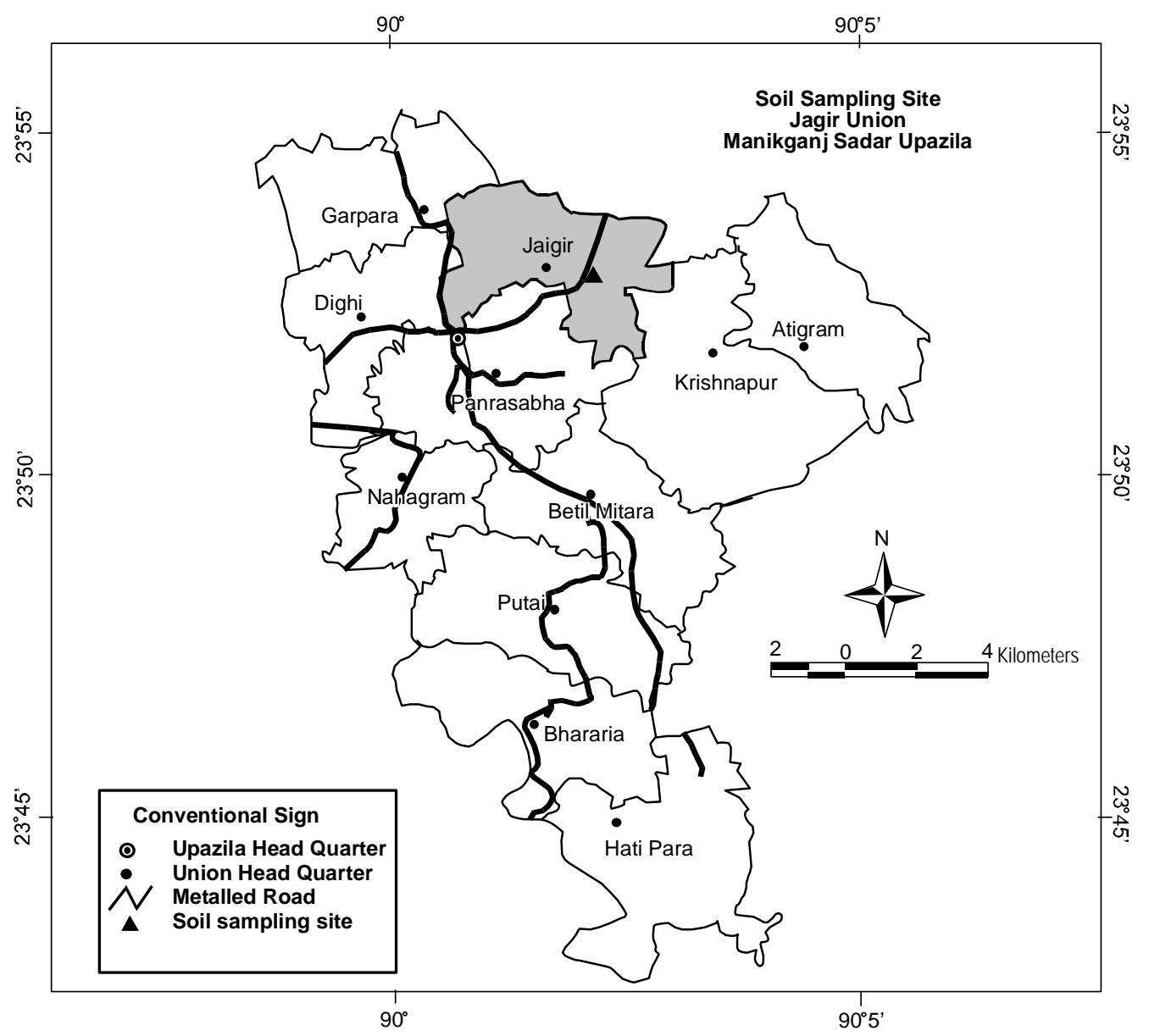

Fig.1. Location map showing the experimental area. 
The treatments were: $T_{0}$ (control), $T_{1}$ (poultry litter), $T_{2}$ (cow dung), $T_{3}$ (rice straw), $T_{4}$ (sewage sludge), $T_{5}$ (recommended dose of fertilizers). There were three replications for each treatment totaling 18 individual plots. The area of each plot was $4 \mathrm{~m} \times 5 \mathrm{~m}$ having plot to plot, block to block and peripheral spacing of $1 \mathrm{~m}$. Line to line distance in each plot was $30 \mathrm{~cm}$ and plant to plant distance was $10 \mathrm{~cm}$. Fig. 2 shows the layout of the experimental field.

Experimental field was well prepared with spade followed by harrowing. The individual plots were made $7.5 \mathrm{~cm}$ high and $20 \mathrm{~cm}$ deep, drainage were made around the plot to restrict the lateral runoff of irrigation or rainfall water and the deepness of drains was maintained up to the harvest of crop. All sources of organic wastes namely, cow dung, rice straw, poultry litter and sewage sludge were incorporated with the soil @ 5 t/ha during land preparation. Recommended dose of fertilizers was applied according to the fertility status of the soil under study and fertilizer doses were maintained as per recommendion of the Fertilizer Recommendation Guide (BARC, 2005). Application rate of fertilizers are shown in Table 1.

Seeds of kenaf (H. cannabinus L.) variety CPI-72126 were collected from the Seed Division of Bangladesh Jute Research Institute (BJRI). Seeds were sown @ 12 $\mathrm{kg} / \mathrm{ha}$ by hand in narrow and shallow furrows made

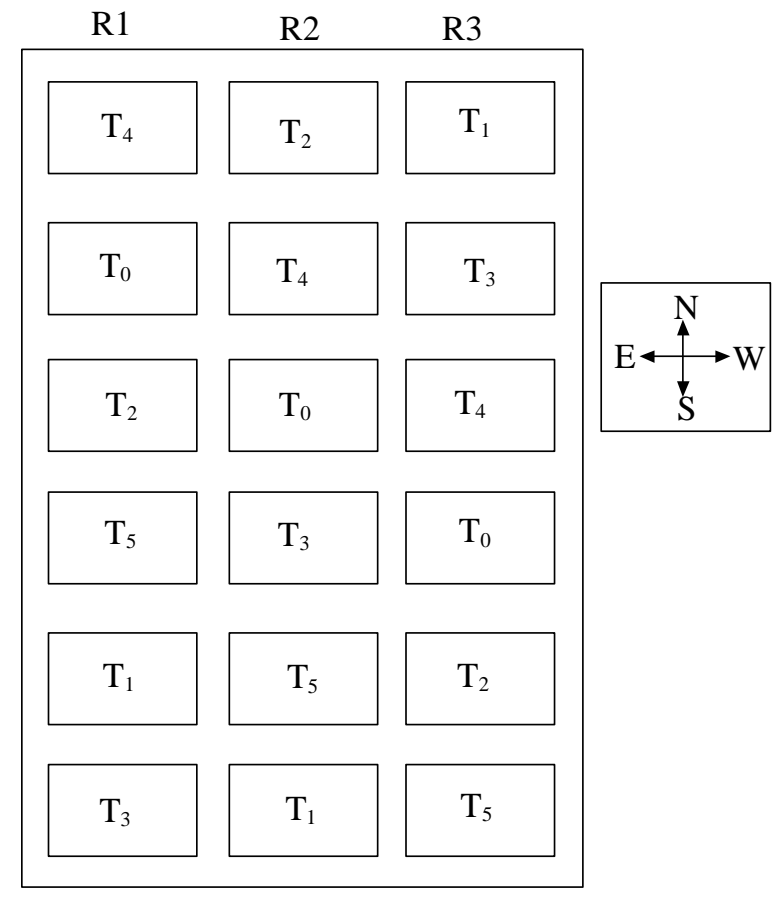

Fig. 2. Layout of the experimental field.
Table 1. Recommended dose of fertilizers (RDF) applied during cultivation of kenaf (Hibiscus cannabinus L.)

\begin{tabular}{lll}
\hline \hline \multirow{2}{*}{ Fertilizer } & \multicolumn{2}{c}{ Time of application } \\
\cline { 2 - 3 } & At SSD & After 45 days \\
\hline Urea & $60 \mathrm{~kg} / \mathrm{ha}$ & $66 \mathrm{~kg} / \mathrm{ha}$ \\
TSP & $25 \mathrm{~kg} / \mathrm{ha}$ & - \\
MP & $40 \mathrm{~kg} / \mathrm{ha}$ & - \\
\hline
\end{tabular}

*SSD = seed sowing day, (Source: Fertilizer Recommendation Guide, BARC, 2005).

with iron rod. Immediately after sowing, a common irrigation was given by furrow irrigation system to ensure germination of seeds. The second installment of irrigation was given 30 days after sowing and the third installment given 45 days after sowing of seeds. The moisture content of soil of the experimental field was maintained between 50 and $80 \%$ field capacity throughout growing period. Field capacity was measured following the procedure as described by Huq and Alam (2005). Soil samples were analyzed for their moisture contents and supplemental irrigation was applied to maintain the moisture level at the field capacity. Thinning and weeding were done at 15,30 and 45 days after sowing, respectively. No pesticides were applied during the experiment period. Kenaf (H. cannabinus L.) was harvested at 120 days of maturity (at flowering stage). Plant height, base diameter, stem density and green weight were measured at the time of harvesting.

Field measurements and calculations. Growth and dry biomass productivity was monitored by means of subsequent destructive sampling at the time of harvesting. During harvesting 100 plants were selected randomly from each plot considering the border effect. The plants were uprooted manually, the fresh weight measured at the field and 25 plants were randomly chosen for plant height and base diameter measured in the field. Stem density was measured by making a square shape frame with $1 \mathrm{~m} \times 1 \mathrm{~m}$ bamboo which were inserted into each plot and the plant in the square shape were counted to calculate the number of plant per square meter. Average of stem density for each treatment was made from replicated plots. Plant height and base diameter were determined as the average for all harvested plants per plot from plants that were selected randomly from the uprooted samples. The harvested plant samples were taken into the laboratory and plant fractions were oven-dried at $90{ }^{\circ} \mathrm{C}$ until constant weights (for 3-4 days) were obtained to determinate the respective dry weights. 
Plant height, base diameter and stem density of kenaf were used to study plant growth.

Collection and preparation of soil and organic wastes. Before initiation of the experiment, the soil sample representing 0-15 cm depth from surface were collected by composite soil sampling method as suggested by the soil survey staff of the USDA (1951), to determine some major physical and chemical properties of soil of the experimental field. The soil samples were collected with the help of an augur and were put in polythene bags. The collected soil samples were dried in air for three days by spreading them on a thin layer of plastic paper and visible roots and debris were removed from the soil samples. After air-drying, a portion of the larger and massive aggregates were broken gently crushing them by a wooden hammer. Grounded soil samples were screened to pass through a $2 \mathrm{~mm}$ sieve and the samples were then mixed thoroughly for making the composite sample. These soil samples were used for various physical analyses. Another portion of the soil samples screened to pass through a $0.5 \mathrm{~mm}$ sieve. The sieved samples were mixed thoroughly for making composite samples and preserved in the same way as above. These soils were used for chemical and physicochemical analyses.

Organic wastes such as poultry litter, rice straw and well decomposed cow dung were collected from nearby areas of Jute Agricultural Experimental Station, Bangladesh Jute Research Institute, Manikganj and sewage sludge was collected from Sayedabad Sewage Treatment Plant, Dhaka. The collected poultry litter, sewage sludge and cow dung were air dried for several days and ground to pass $0.5 \mathrm{~mm}$ sieve before application in the experimental field. The bulk of rice straw was collected from the surrounding paddy field near the experimental site. The collected rice straw was air dried and chopped into small pieces before applying to the field. Sewage sludge, cow dung, rice straw and poultry litter were collected for laboratory analysis from the bulk collection and were put in polythene bags, tagged with rubber band and labeled. For the preparation of organic waste samples for chemical analysis, similar procedures were followed as for the preparation of soil samples.

Laboratory analysis. Organic wastes and soil samples collected from the experimental field were analyzed in the laboratory for various physical and chemical properties. The methods by Huq and Alam (2005) were used for the analysis of the organic wastes and soil samples. Soil samples were extracted by using aquaregia $\left(\mathrm{HNO}_{3}\right.$ and $\mathrm{HCl}$ at the ratio of 1:3) for the determination of total phosphorous, potassium, iron, manganese and zinc while digestion of the organic materials was done by $\mathrm{HNO}_{3}$ and $\mathrm{HClO}_{4}$ acid mixture (Portman and Riley, 1964) for the determination of total phosphorous, potassium, iron, manganese and zinc. Iron, manganese and zinc in the extract were estimated by Atomic Absorption Spectrometer (AAS). For every 10 samples, a certified reference material (CRM) was included to ensure the QC/QA. Total nitrogen of soil and organic wastes was determined by alkali distillation of the Kjeldahl digest; organic carbon was determined by Walkley and Black wet oxidation method (Jackson, 1958) total $P$ was determined spectrophotometrically by developing the vanado-molybdate yellow colour; $\mathrm{K}$ was determined by flame analyzer (Huq and Alam, 2005). The $\mathrm{pH}$ was determined by $\mathrm{pH}$ meter and textural class was determined by Marshall's triangle after conducting particle size analysis as described by Huq and Alam (2005).

Statistical analysis. All measured and derived data were subjected to analysis of variance (ANOVA) using statistical software MINITAB (version 15) following the experimental design. As test criterion for looking differences between means the LSD $\mathrm{L}_{0.05}$ was used (Gomez and Gomez, 1976).

\section{Results and Discussion}

Collected organic wastes and soil samples from the experimental field were analyzed in the laboratory before set up of the experiment to know the nutrient status. The results are presented in Tables 2 and 3.

Growth indices. Plant height. Mean plant height of kenaf (H. cannabinus L.) was found to be affected significantly by the type of organic wastes applied. The plant height of kenaf grown in soil treated with different sources of organic wastes were found to be significantly different from the control plants $(\mathrm{F}=$ $\left.11.08^{* *}\right)$. The mean plant height of kenaf was better with sewage sludge than either with the recommended dose of fertilizers or control (Fig. 3). The mean height of the kenaf plants due to sewage sludge application was $1.90 \mathrm{~m}$ followed by cow dung $(1.84 \mathrm{~m})$, poultry litter $(1.81 \mathrm{~m})$, and rice straw $(1.71 \mathrm{~m})$, respectively. The mean plant heights for cow dung, poultry litter and recommended dose of fertilizer treatments were 
statistically similar. Application rate of $5 \mathrm{t} / \mathrm{ha}$ of sewage sludge, cow dung and poultry litter produced $6.74 \%$, $3.37 \%$ and $1.69 \%$ higher mean plant height, respectively over the control plot (with no organic waste application).

Results show that the application of organic waste played a significant role to increase the mean plant height of kenaf ( $H$. cannabinus L.). Yield components such as plant height, stem density and biomass production of kenaf can significantly be affected by the fertility of the soil. Mullens (1998) in Mexico reported

Table 2. Physical, physico-chemical and chemical properties of the soils of experimental field

\begin{tabular}{ll}
\hline \hline Soil properties & Value \\
\hline Particle size analysis & \\
Sand (\%) & 17.456 \\
Silt (\%) & 62.246 \\
Clay (\%) & 20.298 \\
Textural class & Silt loam \\
pH & 7.2 \\
Organic carbon (\%) & 0.65 \\
Organic matter (\%) & 1.11 \\
Field capacity (\%) & 35.86 \\
Moisture content (\%) & 8.25 \\
Total nitrogen (\%) & 0.0567 \\
Total phosphorous (mg/kg) & 768.50 \\
Available phosphorous (mg/kg) & 30 \\
Total potassium (mg/kg) & 2121.93 \\
Available potassium (mg/kg) & 63.33 \\
Iron (mg/kg) & 21289.06 \\
Manganese (mg/kg) & 382.66 \\
Zinc (mg/kg) & 130.58 \\
\hline \hline
\end{tabular}

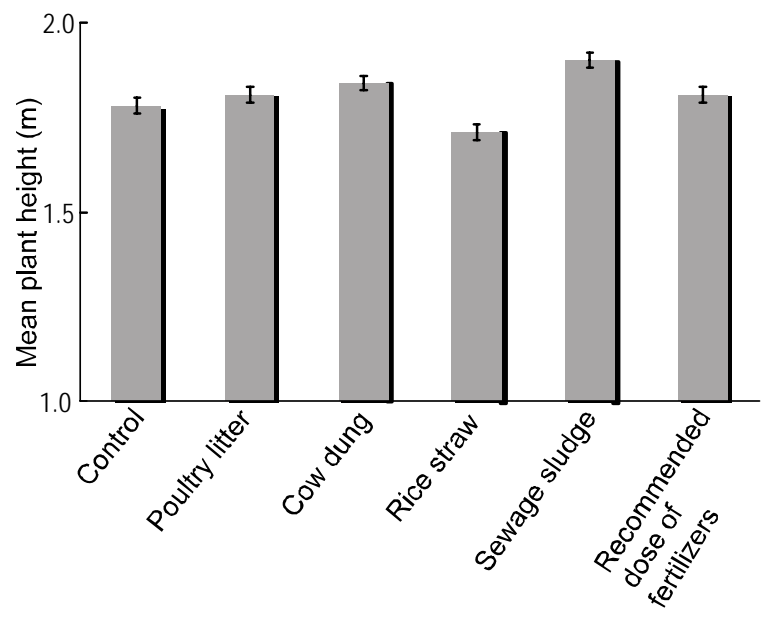

Fig. 3. Mean plant height of kenaf (Hibiscus cannabinus L.) at different sources of organic waste application.

that seed production on rich soils or high fertilizer applications complicated seed harvest by increasing plant vegetation and plant height. Researchers in Florida (Seale et al., 1952) reported decreased seed yields, increased plant height, plant density and plant vegetation on fertile peat soils as compared to moderately fertile sandy soils.

Base diameter. The base diameter of kenaf $(H$. cannabinus L.) plants grown on soil treated with different sources of organic wastes was positively affected. However, no statistical significant differences $(P>0.05)$ were found among the treatments applied (Fig. 4). The highest mean base diameter of kenaf plants was observed at the recommended dose of fertilizers applied plot which was $8.59 \mathrm{~cm}$. Among the four sources of organic waste mean plant base diameter in sewage sludge treated

Table 3. Physical, physico-chemical and chemical characteristics of organic wastes applied to the field

\begin{tabular}{lllll}
\hline \hline \multirow{2}{*}{ Parameter } & \multicolumn{4}{c}{ Organic wastes } \\
\cline { 2 - 5 } Moisture content (\%) & 38.06 & 44.60 & 8.32 & Rice straw \\
$\mathrm{pH}(\%)$ & 3.82 & 6.76 & 5.87 & 9.05 \\
Organic Carbon (\%) & 8.56 & 5.96 & 9.49 & - \\
Total Nitrogen (\%) & 1.38 & 2.23 & 1.8 & 25.43 \\
Total Phosphorous (mg/kg) & 4944.30 & 3194.35 & 4497.04 & 0.68 \\
Total Potassium (mg/kg) & 1361.70 & 223.57 & 1991.80 & 694.43 \\
Iron (mg/kg) & 2925.23 & 2256.75 & 2318.56 & 713.70 \\
Manganese (mg/kg) & 195.72 & 240.27 & 434.40 & 209.94 \\
Zinc (mg/kg) & 943.75 & 285.13 & 186.59 & 35.23 \\
\hline \hline
\end{tabular}




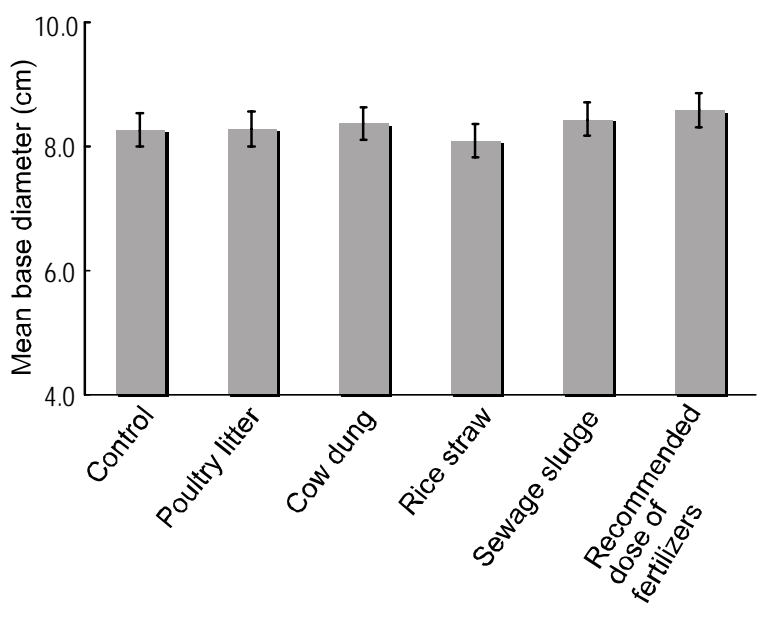

Fig. 4. Mean base diameters of kenaf (Hibiscus cannabinus L.) at different sources of organic waste application.

plot was $8.45 \mathrm{~cm}$ followed by cow dung $(8.38 \mathrm{~cm})$ poultry litter $(8.29 \mathrm{~cm})$ and rice straw $(8.09 \mathrm{~cm})$ applied plot. In the experiment of McMillin et al. (1998) dry biomass weight of kenaf ( $H$. cannabinus L.) was positively correlated with base diameter and total plant yield (i.e. biomass) and was significantly correlated with stem diameter and weight but not height. The results from the experiment were consistent with earlier reports that basal diameter increased with increasing plant height (Webber, 1993b; Higgins and White, 1970). However, Webber's (1993a, 1993b) findings were that the stalk yield of kenaf was correlated with plant height, but McMillin et al. (1998) found that stalk weight and total plant yield were more closely correlated with stalk diameter.

Stem density. Stem density was significantly different among the treatments. Mean stem density of kenaf per square meter plot at different sources of organic waste application are presented in Fig. 5. Significant statistical differences in the mean stem density were found for all the sources of organic wastes application $\left(\mathrm{F}=678.48^{* *}\right)$. The highest mean stem density of 67.33 plants $/ \mathrm{m}^{2}$ was observed for sewage sludge applied plot $(* \mathrm{P}<0.05)$ followed by poultry litter (66.67 plants $/ \mathrm{m}^{2}$ ), cow dung (62.67 plants $/ \mathrm{m}^{2}$ ) and rice straw (53.33 plants $/ \mathrm{m}^{2}$ ) applied plot, respectively. In rice straw applied plot stem density was statistically similar with that of control plot. Stem densities were $27.04 \%$ higher in sewage sludge, $25.79 \%$ in poultry litter and $18.24 \%$ in cow dung applied plot compared with that of control plot (no organic waste application). It is obvious from the

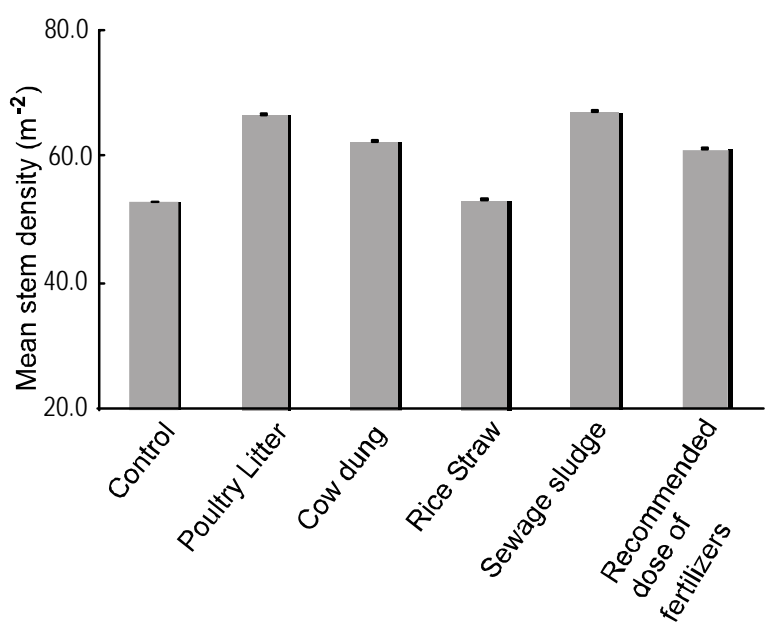

Fig. 5. Mean stem density of kenaf (Hibiscus cannabinus L.) at different sources of organic waste application.

experiment that the applications of organic waste increase the mean stem density significantly.

Apparently, under the prevailing climatic conditions, maximum biomass productivity of $H$. cannabinus L. was obtained even with a population of 67.33 plants $/ \mathrm{m}^{2}$ from sewage sludge applied plot. In this experiment it should be noticed that lower branching and higher basal stem diameters were observed in the higher densities along with different sources of organic wastes application. From Muchow (1979) findings, it is shown that at higher stem densities ( $>37$ plants $/ \mathrm{m}^{2}$ ) kenaf compensates for the available environmental resources by reducing the plant number. From our experiments it seems that kenaf individual plants are able to manipulate their growth at different sources of organic wastes application in response to stem density while influencing growth rates and biomass productivity. Additionally, stem density comprises an important factor influencing the biomass yield. Kenaf compensates well across a wide range of stem density i.e. $10-90$ plants $/ \mathrm{m}^{2}$; (Muchow, 1979), while it seems that a stem density of 18-37 plants $/ \mathrm{m}^{2}$ may be desirable for maximizing biomass yield (Webber and Bledsoe, 2002; Alexopoulou et al., 2000; Carberry and Muchow, 1992).

Biomass production. Total biomass yield represents the combined oven-dried weights of all of the above ground plant material (stalks and leaves). Obtained biomass (dry weight basis) are expressed in t/ha and shown in Fig. 6. Biomass production of kenaf grown on soil treated with different sources of organic wastes were significantly affected by the materials at $1 \%$ level 


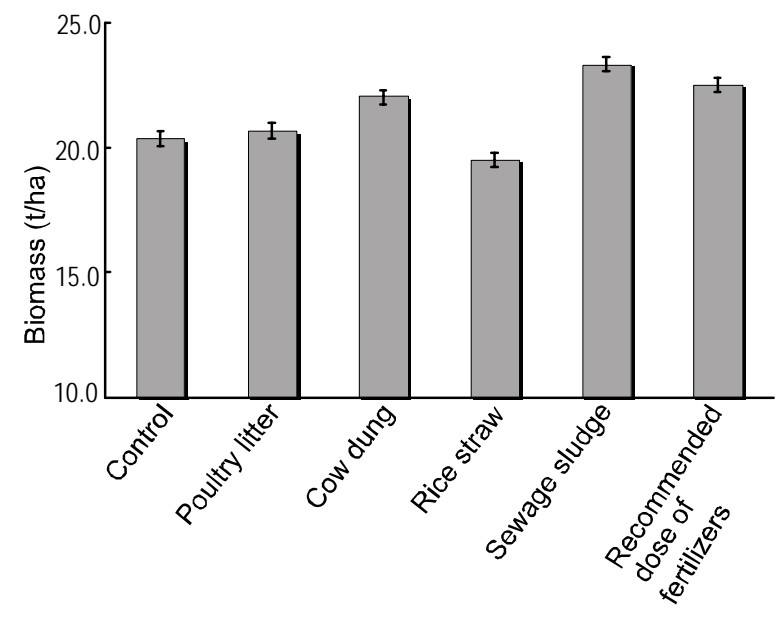

Fig. 6. Mean base biomass of kenaf (Hibiscus cannabinus L.) at different sources of organic waste application.

$(F=26.90)$. Significant statistical differences in biomass productivity were found for all the sources of organic wastes application (Fig. 6). Among the four sources of organic waste the highest biomass production of kenaf was observed to be $23.33 \mathrm{t} / \mathrm{ha}$ for the sewage sludge applied plot followed by $22.03 \mathrm{t} /$ ha for cow dung, 20.67 t/ha for poultry litter and $19.50 \mathrm{t} /$ ha for rice straw applied plot. The mean biomass production of kenaf in sewage sludge, cow dung and poultry litter applied plots were $14.64 \%, 8.26 \%$ and $1.57 \%$ higher, respectively than the control plot. The obtained biomass productivities of kenaf here are among the highest reported worldwide (12.4 to 23.9 t/ha and a growing cycle of 130-180 days; (Baldwin and Graham, 2006; Bhardwaj et al., 2005; Banuelos et al., 2002; Amaducci et al., 2000; Belocchi et al., 1998; McMillin et al., 1998; Manzanares et al., 1997; 1993; Carberry et al., 1992).

Among the four sources of organic waste application, sewage sludge produced significantly highest biomass which can be used as a potential source of organic matter amendment in soil for kenaf production. Slightly increased biomass production with the sewage sludge application on two kenaf ( $H$. cannabinus L.) cultivars ('Everglades 41' and 'Tainung 2') was also observed by Andrés et al. (2010). In the greenhouse experiment conducted by Andrés et al. (2010) the application of sewage sludge increased the total dry biomass production of Everglades 41 from $7.20 \mathrm{~g}$ per pot in the control to $12.51 \mathrm{~g}$ and $14.92 \mathrm{~g}$ per pot in the 10 and $20 \mathrm{Mg} / \mathrm{ha}$ sewage sludge treatments (mean values for the two sewage sludges), respectively. On the other hand poultry litter may also be used to produce kenaf as its performance is similar to sewage sludge application in our experiment. Both sewage sludge and poultry litter had a positive effect on kenaf production and quality. Similar results were reported by Cogger et al. (2001) who applied different rates of biosolids to forage grasses, and by Hirzel et al. (2007) in a field trial investigating the effect of poultry litter on silage maize. This result again suggests that, in the short term, both wastes supply the similar amount of plant-available N. Other authors have reported similar results ( Hirzel et al., 2007; Cogger et al., 2004; Smith and Durham, 2002). These wastes could be a good substitute for the synthetic N, P and $\mathrm{K}$ fertilizers and cause no apparent crop damage nor do they result in toxic plant tissue.

\section{Conclusion}

The results obtained in this study provide an indication that organic wastes (sewage sludge, poultry litter, cow dung) at the rates applied can increase growth and biomass production of kenaf (H. cannabinus L.). The ability of sewage sludge, poultry litter and cowdung to increase growth and biomass production clearly indicate that these organic materials could be used to increase production of kenaf while the management problems of these waste materials are solved. Nevertheless, longterm field studies are needed to obtain more accurate assessments of their fertilizing capacity and environmental impact on other varieties of kenaf at different geographical location and varying soil condition.

\section{Acknowledgement}

The authors would like to acknowledge the Bangladesh Australia Centre for Environmental Research (BACER-DU), University of Dhaka, for providing laboratory facilities and Bangladesh Jute Research Institute (BJRI) for providing support regarding field experiment.

\section{References}

Alexopoulou, E., Papatheohari, Y., Kipriotis, E. 2007. Response of kenaf (Hibiscus cannabinus L.) growth and yield to nitrogen fertilization. International Journal of Food, Agriculture and Environment, 5: 228-232.

Alexopoulou, E., Christou, M., Nicholaou, A., Mardikis, M. 2004. Biokenaf: a network for industrial products and biomass for energy from kenaf. In: Proceedings 
of the $2^{\text {nd }}$ World Biomass Conference: Biomass for Energy, Industry and Climate Protection, W.P.M. Van Swaalj (ed.), pp. 2040-2043, (10-14 May 2004), Rome, Italy.

Alexopoulou, E., Christou, M., Mardikis, M., Chatziathanasiou, A. 2000. Growth and yields of kenaf varieties in central Greece. Industrial Crops Products, 11: 163-172.

Amaducci, S., Amaducci, M.T., Benati, R., Venturi, G. 2000. Crop yield and quality parameters of 4 annual fiber crops (hemp, kenaf, maize, sorghum) in the North of Italy. Industrial Crops Products, 11: 179186.

Andrés, E.F., Tenorio, J.L., Walter, I. 2010. Biomass production and nutrient concentration of kenaf grown on sewage sludge-amended soil. Spanish Journal of Agricultural Research, 8: 472-480.

Baldwin, B.S., Graham, J.W. 2006. Population density and row spacing effects on dry matter yield and bark content of kenaf (Hibiscus cannabinus L.). Industrial Crops Products, 23: 244-248.

Banuelos, G.S., Bryla, D.R., Cook, C.G. 2002. Vegetative production of kenaf and canola under irrigation in central California. Industrial Crops Products, 15: 237-245.

BARC. 2005. Fertilizer Recommendation Guide 2005, M.U.T. Miah, A.T.M. Farid, M.A.M. Miah, M. Jahiruddin, S.M.K. Rahman, M.A. Quayyum, M.A. Sattar, M.A. Motalib, M.F.M. Islam, Ahsan, R. Sultana, (eds.), pp. 1-260, BARC Soil Publication no. 45. Farmgate, Dhaka, Bangladesh.

Bassam, N. El. 1998. Kenaf. In: Energy Plant Species: Their Use and Impact on Environment and Development. pp. 169-172, James \& James (Science Publisher) Ltd., 35-47 William Road, London, UK.

Belocchi, A., Quaranta, F., Desiderio, E. 1998. Yields and adaptability of kenaf varieties (Hibiscus cannabinus) for paper pulp in central Italy. In: Sustainable Agriculture for Food, Energy and Industry, pp. 1039-1049, James \& James (Science Publishers) Ltd., 35-47 William Road, London, UK.

Bhardwaj, H.L., Webber, C.L., Sakamoto, G.S. 2005. Cultivation of kenaf and sunhemp in the midAtlantic United States. Industrial Crops Products, 22: 151-155.

Carberry, P.S., Muchow, R.C., Williams, R., Sturtz, J.D., McCown, R.L. 1992. A simulation model for kenaf assisting fiber industry planning in northern Australia. I. General introduction and phonological model. Australian Journal of Agricultural Research, 43: 1501-1513.

Carberry, P.S., Muchow, R.C. 1992. A simulation model for kenaf assisting fiber industry planning in northern Australia. II. Leaf area Development. Australian Journal of Agricultural Research, 43: 1515-1526.

Cogger, C.G., Bary, A.I., Sullivand, D.M., Myhre, E.A. 2004. Biosolids processing effects on first and second year available nitrogen. Soil Science Society of America Journal, 68: 162-167.

Cogger, C.G., Bary, A.I., Fransen, S.C., Sullivan, D.M. 2001. Seven years of biosolids versus inorganic nitrogen application to tall fescue. Journal of Environmental Quality, 30: 2188-2194.

Cuevas, G., Martinez, F., Walter, I. 2003. Field grown maize (Zea mays L.) with composted sewage sludge: Effects on soil and grain quality. Spanish Journal of Agricultural Research, 1: 111-119.

DeLaune, P.B., MooreJr, P.A., Carman, D.K., Sharpley, A.N., Haggard, B.E., Danier, T.C. 2004. Evaluation of the phosphorus source component in the phosphorus index for pastures. Journal of Environmental Quality, 33: 2192-2200.

Francois, L.E., Donovan, T.J., Mass, E.V. 1992. Yield, vegetative growth and fiber length of kenaf grown on saline soil. Agronomy Journal, 84: 592-598.

Gomez, K.A., Gomez, A.A. 1976. Statistical Procedures for Agricultural Research with Emphasis on Rice, pp. 97-104, International Rice Research Institute, Los Banos, Philippines.

Higgins, J.J., White, G.A. 1970. Effects of plant populations and harvest date on stem yield and growth components of kenaf in Maryland. Agronomy Journal, 62: 667-668.

Hirzel, J., Matus, I., Novoa, F., Walter, I. 2007. Effect of poultry litter on silage maize (Zea mays L.) production and nutrient uptake. Spanish Journal of Agricultural Research, 5: 102-109.

Huq, S.M.I., Alam, M.D. 2005. A Hand Book on Analyses of Soil, Plant, and Water, pp. xxii+246, BACER-DU, University of Dhaka, Dhaka, Bangladesh.

Jackson, M.L. 1958. Soil Chemical Analysis. 498 pp., Prentice - Hall Inc., Englewood Cliffs, N. J., USA.

Korboulewasky, N., Dupouyet, S., Bonin, G. 2002. Environmental risk of applying sewage sludge compost to vineyards: carbon, heavy metals, nitrogen and phosphorus accumulation. Journal of Environmental Quality, 31: 1522-1527. 
Krogmann, U., Qu, M., Boyles, L.S., Martel, C.J. 1998. Biosolids and sludge management. Water Environment Research, 70: 557-580.

Manzanares, M., Tenorio, J.L., Ayerbe, L. 1997. Sowing time, cultivar, plant population, and application of $\mathrm{N}$ fertilizer on kenaf Spain's central plateau. Biomass and Bioenergy, 12: 263-271.

Manzanares, M., Tenorio, J.L., Manzanares, P., Ayerbe, L. 1993. Yield and development of kenaf (Hibiscus canabinus L.) crop in relation to water supply and intercepted radiation. Biomass and Bioenergy, 5: 337-345.

McBride, M.B., Richards, B.K., Steenhuis, T. 2004. Bioavailability and crop uptake of trace elements in soil columns amended with sewage sludge products. Plant and Soil, 262: 71-74.

McBride, M.B., Richards, B.K., Steenhuis, T., Spiers, G. 1999. Long-term leaching of trace elements in a heavily sludge-amended silty clay loam soil. Soil Science, 164: 613-623.

McMillin, J.D., Wanger, M.R., Webber, C.L., Mann, S.S., Nichols, J.D., Jech, L. 1998. Potential for kenaf cultivation in south-central Arizona. Industrial Crops Products, 9: 73-77.

Meints, P.D., Smith, C.A. 2003. Kenaf seed storage duration on germination, emergence and yield. Industrial Crops Products, 17: 9-14.

Misslebrook, T.H., Shepard, M.A., Pain, B.F. 1996. Sewage sludge applications to grassland: influence of sludge type, time and method of application on nitrate leaching and herbage yield. The Journal of Agricultural Science, 126: 343-352.

Muchow, R.C., Carberry, P.S. 1993. A simulation model for kenaf assisting fiber industry planning in northern Australia. V. Impact of different crop trait. Australian Journal of Agricultural Research, 44: 731-744.

Muchow, R.C. 1992. Effect of water and nitrogen supply on radiation interception and biomass accumulation of kenaf (Hibiscus cannabinus) in a semi-arid tropical environment. Field Crop Research, 28: 281-293.

Muchow, R.C. 1979. Effects of plant population and season on kenaf (Hibiscus cannabinus L.) grown under irrigation in tropical Australia. II. Influence on growth parameters and yield prediction. Field Crops Research, 2: 67-76.

Muir, J.P. 2002. Effect of dairy compost application and plant maturity on forage kenaf cultivar fiber concentration and in Sacco disappearance. Crop
Science, 42: 248-254.

Muir, J.P. 2001. Dairy compost, variety, and stand age effects on kenaf forage yield, nitrogen and phosphorus concentration and uptake. Agronomy Journal, 93: 1169-1173.

Mullens, D.B. 1998. Critical considerations in commercial kenaf seed production. In: Proceedings of First Annual American Kenaf Society Conference, pp. 90-95, February 25-26, 1998, Menger Hotel, San Antonio, TX, USA.

Nelson, G.H., Nieschlag, H.J., Wolff, I.A. 1962. A search for new, fiber crops. V. Pulping studies on kenaf. (TAPPI) The Technical Associantion of the Pulp and Paper Industry Journal, 45: 780-786.

Nielsen, D.C. 2004. Kenaf forage yield and quality under varying water availability. Agronomy Journal, 96: 204-213. DOI No: 10.2134/agronj2004.2040.

Nieschlag, H.J., Nelson, G.H., Wolff, I.A., Perdue, R.E. 1960. A search for new fiber crops. TAPPI Journal, 43: 193-201.

Pate, J.B., Seale, C.C., Gangstad, E.O. 1954. Varietal studies of kenaf, Hibiscus cannabinus L., in South Florida. Agronomy Journal, 46: 75-77.

Portman, J.E., Riley, J.P. 1964. Determination of Arsenic in seawater, marine plants \& silicate and carbonate sediments. Analytica Chimica Acta, 31: 509-519.

Quaranta, E., Belocchi, A., Bottazzi, P., Monotti, M., Del Pino, A.M., Desiderio, E. 2000. Limited water supply on kenaf (Hibiscus cannabinus L.) in central Italy. Italian Journal of Agronomy, 4: 1-9.

Richards, B.K., Steenhuis, T.S., Peverly, J.H., Mcbride, M.B. 2000. Effect of sludge-processing mode, soil texture and soil $\mathrm{pH}$ on metal mobility in undisturbed soil columns under accelerated loading. Environmental Pollution, 109: 327-346.

Seale, C.C., Joyner, J.F., Gangstad, E.O. 1952. The experimental culture of kenaf, Hibiscus cannabinus L. for fiber and seed in South Florida. Turrialba, 2: 99-105.

Shober, A., Stehouwer, R.C., Macneal, K.E. 2003. Onfarm assessment of biosolids effects on soil and crop tissue quality. Journal of Environmental Quality, 32: 1873-1880.

Sims, J.T., Pierzynski, G.M. 2000. Assessing the impact of agricultural municipal and industrial by-products on soil quality. In: Beneficial Uses of Land Applied Agricultural, Municipal and Industrial By-products, pp. 237-261, J.F. Power (ed.), SSSA Special Publication No-6, SSSA, Madison, WI, USA 
Smith, S.R., Durham, E. 2002. Nitrogen release and fertilizer value of thermally-dried biosolids. Water and Environment Journal, 16: 121-126.

Taylor, C.S., Kugler, D.E. 1992. Kenaf: annual fiber crop products generate a growing response from industry. In: Year-Book of Agriculture 1992, pp. 92-98, Rural Development Publications Collection, USDA, Washington DC, USA.

USDA. 1951. Soil Survey Manual by Soil Survey Staff, Bureau of Plant Industry. Soil and Agricultural Engineering, Handbook No. 18, 205 pp, USDA, Washington DC, USA.

Walter, I., Martinez, F., Cala, V. 2006. Heavy metal speciation and phytotoxic effects of three representative sewage sludge for agricultural uses. Environmental Pollution, 139: 507-514.

Waste Concern. 2005. CDM Project Potential in the Poultry Waste Management Sector in Bangladesh, Banani Model Town, Dhaka, Bangladesh.

Westerman, P.W., Bicudo, J.R. 2005. Management considerations for organic waste use in agriculture. Bioresource Technology, 96: 215-221.

Webber, C.L., Bledsoe, V.K. 2002. Kenaf yield components and plant composition. In: Trends in New Crops and New Uses, J. Janick \& A. Whipkey (eds.), pp. 348-357, ASHS Press, Alexandia, VA, USA.

Webber, C.L. 1996. Response of kenaf to nitrogen fertilization. In: Progress in New Crops, J. Janick (ed.), pp. 404-408, ASHS Press, Arlington, VA, USA.

Webber, C.L. 1993a. Crude protein and yield components of six kenaf cultivars as affected by crop maturity. Industrial Crops Products, 2: 27-31.

Webber, C.L. 1993b. Yield components of five kenaf cultivars. Agronomy Journal, 85: 533-535.

Webber, C.L., Bledsoe, R.E., 1993. Kenaf: Production, harvesting, and products. In: New Crops, J. Janick \& J.E. Simon (eds.), pp. 416-421, Wiley, New York, USA.

Wen, G.T., Bates, E., Voroney, R.P., Winter, J.P., Schellenbert, M.P. 1997. Comparison of phosphorus availability with application of sewage sludge, sludge compost and manure compost. Communications in Soil Science and Plant Analysis,28: 1481-1497.

White, G.A., Cummins, D.G., Whiteley, E.L., Fike, W.T., Greig, J.K., Martin, J.A., Killinger, G.B., Higgins, J.J., Clark, T.F. 1970. Cultural and harvesting methods for kenaf: an annual crop source of pulp in the Southeast. USDA Agricultural Research Service Production Research Report, Issue no-113, 38 pp.Washington DC, USA.

Wilson, F.D., Summers, T.E., Joyner, J.F., Fishler, D.W., Seale, C.C. 1965. 'Everglades 41' and 'Everglades 71', two new cultivars of kenaf (Hibiscus cannabinus L.) for the fiber and seed. Florida Agricultural Experiment Station Circular S-168.

Wood, I.M., Muchow, R.C., Ratcliff, D. 1983. Effect of sowing date on the growth and yield of kenaf (Hibiscus cannabinus) grown under irrigation to tropical Australia II. Stem production. Field Crop Research, 7: 91-102.

Wood, I.M., Muchow, R.C. 1980. Estimation of optimal rate of application of nitrogen for kenaf (Hibiscus cannabinus) harvested at different ages for paper pulp production. CSIRO Division of Tropical Crops and Pastures. Tropical Agronomy Technical Memorandum, Issue no. 25, pp. 8. 